\title{
PARAMETERS AFFECTING CATCH OF LIGHTBROWN APPLE MOTH IN PHEROMONE-TREATED ORCHARDS
}

\author{
D.M. SUCKLING and G. KARG \\ HortResearch PO Box 51, Lincoln
}

\begin{abstract}
Catches in sticky traps with the standard loading of $100 \mu \mathrm{g}$ of pheromone on rubber septa are normally suppressed inside blocks treated for mating disruption, indicating successful treatment, Traps would be useful for monitoring the presence and timing of moth flights inside disrupted blocks. This experiment aimed to determine the loading of pheromone for lures capable of catching moths inside treated areas. Traps were baited with $0,100 \mathrm{ig}, 300 \mathrm{pg}, 1 \mathrm{mg}, 3 \mathrm{mg}$, or $10 \mathrm{mg}$ of pheromone, and placed in either pheromone-treated (1000 polyethylene dispensers per ha) or untreated control plots ( $\mathrm{n}=4$ replicates). Traps were checked weekly for five weeks, and rerandomised weekly. Data were transformed by $\log (x+1)$, and analysed by analysis of variance (Fishers' LSD, letters in common between treatments denote no significant difference in catch). The catches (mean, standard deviation, significance) in untreated blocks for each loading ofpheromone were: blank: 0.2(0.4) a; $100 \mu \mathrm{g}$ : 0.8(1.1) a; $300 \mu \mathrm{g}$ : 9.8(1.2) b; $1 \mathrm{mg}: 18.8(0.4)$ be; $3 \mathrm{mg}: 30.2(0.6)$ C; $10 \mathrm{mg}: 22.8(0.4)$ be. In the treated blocks. catches were: blank: $0.0(0.0)$ a, $100 \mu \mathrm{g}: 0.2(0.4)$ a, 300

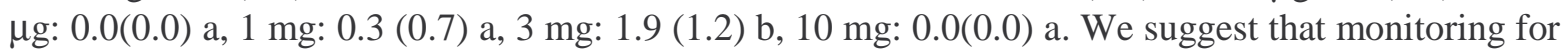
moth presence can be best achieved inside pheromone-treated blocks using lures of $3 \mathrm{mg}$, although phenology could be monitored externally with $100 \mu \mathrm{g}$ lures. Reduced trap catch in treated areas may be explained in part by the reduced electrophysiological responsiveness of antennae in air containing pheromone. Recordings from moth antennae indicated frequent rapid fluctuations in pheromone concentration in the treated orchard, which may be important for disruption.
\end{abstract}

\section{BEHAVIOURAL RESPONSES OF LEPIDOPTERA LARVAE TO ENDOTOXINS AND A COMMERCIAL FORMULATION OF BACILLUS THURINGIENSIS}

\author{
M.O. HARRIS, F. MAFILEO and S. DHANA
}

\section{The Horticulture and Food Research Institute of New Zealand Private Bag 92169, Auckland}

Effects of Bacillus thuringiensis toxins on the behaviour of insects, especially anorexia, have been noted by various researchers but have not been quantified in detailed behavioural assays. We hypothesized that in insects that do not die immediately from the toxic effects of $B t, B t$-induced anorexia occurs in conjunction with increased locomotion which takes larvae away from sites treated with $B t$. To test this hypothesis, we measured behavioural responses of several tortricid pests of apples and kiwifruit (Epiphyas postvittana Planotortrix octo, Ctenopseutsis obliquana, and Cnephasia jactatana) to Bt endotoxins and/or a commercial formulation of Bt. Diets containing these toxins were presented to neonate larvae in both choice and no-choice assays. Larvae did not appear to detect $B t$ toxins prior to ingestion or during initial stages of ingestion. Instead larvae avoided continued ingestion of $B t$ by several sucessive behaviours: a cessation in feeding on diets containing $B t$ followed by abandonment of feeding shelters and increased locomotion. The implications of these results for the management of these New Zealand pests by $B t$ are discussed. 